\title{
GOVOR PREDSEDNIKA DRŽAVNEGA ZBORA DEJANA ŽIDANA OB DNEVU REFORMACIJE 2019 V LJUBLJANI
}

Spoštovani predsednik republike Borut Pahor, visoki in cenjeni gostje, dragi državljanke in državljani, Slovenke in Slovenci!

Zgodovina slovenskega naroda je dolga in bogata. In četudi v očeh drugih nismo bili nikoli največji ali najmočnejši, se obilje našega naroda najjasneje izraža skozi jezikovno in kulturno identiteto; tj. skozi zbirko vrednostnih, materialnih in intelektualnih, tudi duhovnih značilnosti, ki so na neizbrisljiv način zaznamovale našo skupnost.

Dojemanje skupnosti, ki ima svoj temelj v jeziku, ima v evropskem prostoru dolgo domovinsko tradicijo. Da je kontinuiteta jezika edini znak in dokaz narodovega življenja, sicer ne moremo trditi, se pa skozi zgodovino jezika obenem kaže tudi zgodovina naroda, ki ga je govoril. $\mathrm{V}$ jeziku se zrcali moč, razvoj, napredovanje ali nazadovanje naroda $\mathrm{v}$ desetletjih in stoletjih. Je varuh narodovega spomina.

Nocoj, spoštovane in spoštovani, na predvečer državnega praznika obeležujemo prelom časa in civilizacijski preskok v kulturnem in jezikovnem popotovanju slovenskega naroda. Dan reformacije je vedno označen z bogastvom sporočil, a domala vsi največji pomen dajemo začetku razvoja slovenskega knjižnega jezika.

Reformacija je kot gibanje namreč pričevala času, ko je kompleks družbenih dilem močno polariziral takratno družbo. Nenadomestljivo je vplivala na versko, politično, družbeno in kulturno sliko Evrope, ki se je začela izvijati iz preteklih težkih spon v nov preporod. Izjemni posamezniki, kot so Primož Trubar, Jurij Dalmatin, Adam Bohorič 
in Sebastijan Krelj, so ta preporod znali povezati s potrebami naroda. Vzpostavitev lastnega knjižnega jezika v času reformacije je namreč slovenski narod vodila v nadaljnji razvoj.

Slovenščina je za časa Trubarja že imela bogato izročilo in se je uporabljala kot jezik javnega življenja, vendar ni bila nikoli sistematično pisana. Tudi sicer je bila pismenost privilegij le peščice najpremožnejših. Delež pismenega prebivalstva na Slovenskem v 16. stoletju se je namreč gibal med tremi odstotki na začetku in komaj osmimi odstotki ob koncu stoletja.

Trubar si je, resda iz globoko verskih razlogov, prizadeval za opismenjevanje in rabo jezika med vsemi sloji prebivalstva. Protestantsko prepričanje je namreč pomenilo izjemen odmik od tedanje verske prakse. Kot edina prava pot je bila razumljena posameznikova osebna, notranja vera, brez posrednikov med človekom in bogom, kar je pomenilo tudi, da je človekov prvi ali materni jezik postal instrument osebnega razumevanja svetopisemskega izročila.

Pisano besedo je Trubar želel približati večini, preprostim ljudem. S tem jim je bilo dano orodje za enakopravnejše in pravičnejše udejstvovanje v družbeni sferi. Pri nižjem sloju je odklenil potencial ustvarjanja in prispevanja družbi; kdor je to znanje uporabil, je napredoval. Pismenost je tako kot danes pomenila posedovanje kompetenc, ključnih za osebnostno rast posameznika.

Ta korak je od Trubarja zahteval daljnovidnost in širši premislek o jeziku, o vzpostavitvi neke celostne tvorbe, o nadaljnji rabi, tudi razvoju. Zahteval je tudi odgovor na vprašanje, komu je ta jezik namenjen. Pripadnost jeziku je začela postajati pripadnost skupnosti.

To vprašanje pa $\mathrm{v}$ času vihrave evropske zgodovine nikoli ni bilo samo naše. Na tak ali drugačen način se je pojavljalo vsem narodom, $s$ katerimi smo delili skupen, a vedno raznolik in pester evropski prostor.

Ker smo Slovenke in Slovenci svoje zasluženo mesto na zemljevidu Evrope in v svetovni skupnosti narodov dobili zahvaljujoč reformatorjem, se na tem mestu navežem kar na njih. Prav s svojim delovanjem so vselej dokazovali, da ni nasprotja med iskrenim prizadevanjem za 
izboljšanje usode lastnega naroda, kulture in jezika ter širino evropskega duha in njegove različnosti.

Tudi danes, ko smo maloštevilni narodi postavljeni pred zahtevno nalogo varovati dragocenost lastne jezikovne in kulturne edinstvenosti ali sprejemati veličino raznolikosti, ki nas obdaja, se moramo zavedati, da je eno in drugo mogoče samo vzajemno krepiti. Skrb za ohranjanje našega jezika ne pomeni zapiranja ali ograjevanja odprtosti našega duha. Skrb za ohranjanje lastnega jezika ter razvoj in napredek našega naroda zmoremo in moramo izkazovati drugače.

1. Ljubezen do slovenskega naroda in jezika se kaže skozi našo skrb za kulturo, kulturno ustvarjanje in njene ustvarjalce.

To od nas zahteva tudi, da si postavimo ogledalo in priznamo pretekle napake, ko kulture nismo znali postaviti v središče javnega interesa. Danes kultura potrebuje novo reformacijo, nov zagon. To pomeni spodbujanje ustvarjalnosti naših ljudi, še posebej mladih, pri njihovih ambicioznih in inovativnih projektih. Pomeni tudi izboljšanje pogojev delovanja kulturnih ustvarjalcev.

Povečanje dostopnosti do teh kulturnih dobrin čim širši javnosti in vse večje zavedanje pomena kulture kot družbene vrednote si podajata roke. Navsezadnje lahko mi sami to pokažemo z večjim udejstvovanjem v ljubiteljski kulturi, z obiskom predstave v občinskem kulturnem domu, koncerta ali plesnega nastopa mladih učencev lokalne glasbene šole.

2. Ljubezen do slovenskega naroda in jezika se kaže skozi našo skrb za znanost, razvoj in intelektualni naboj skupnosti.

Kritično razmišljanje v maternem jeziku ima svoje korenine prav v izročilu reformacije. Krepitev slovenskega strokovnega in znanstvenega jezika je tako kot na vseh drugih področjih javnega življenja pomembna. Pri tem pa moramo zagotavljati odprtost slovenskega šolskega in znanstvenega prostora, da bo naša država (p)ostala globalno stičišče inovativnih ljudi, idej in znanja.

Ne pozabimo - glas Slovenije v svetu so njeni ljudje, njihovi vrhunski športni dosežki, zgodbe kolektivnega uspeha; nič manj pa tudi izjemna znanstvena dognanja in tehnološke inovacije mnogih Slovenk in 
Slovencev, ki so za naše potrebe in težke izzive prihodnosti globalne družbe našli številne napredne rešitve.

3. Ljubezen do slovenskega naroda in jezika se kaže skozi njegovo javno rabo, podporo pisani besedi in knjigi.

$\mathrm{V}$ času protestantizma je bila odprta prva javna knjižnica. Skupnosti je omogočila prostor, kjer je bilo znanje dostopno vsem. Mnogi bi rekli, da nova digitalna realnost knjižnicam ni naklonjena. A močno verjamem, da bodo ostale kulturno središče naroda in zato jih je treba krepiti tako na lokalni kot nacionalni ravni. Njihova tradicionalna naloga ostaja tudi danes v veliki meri relevantna, dopolnjujejo pa jih nove potrebe in pričakovanja uporabnikov.

Knjižnice naj bodo prostor kreativnosti, kjer vzniknejo sanje in rastejo nove ideje; prostor srečevanja in sodelovanja, ki ga sooblikujejo uporabniki; prostor živahnega študijskega dogajanja in središče akademskih procesov. Naložbo prihodnjega razvoja slovenskega naroda bi tako morali realizirati v novem nacionalnem univerzitetnem stičišču znanja in enemu redkih javnih prostorov slovenske kulture, ki bi bil zgrajen v samostojni državi.

4. Ljubezen do slovenskega naroda in jezika se kaže skozi premišljeno vpeljavo digitalizacije in novih tehnologij.

Za jezik in kulturo velja, da sta razpeta med tradicijo in inovacijo. Tega, da smo Slovenci bralni narod, vse prodornejše digitalno okolje ne bo spremenilo. $V$ resnici beremo in pišemo več, kot so ljudje kadarkoli brali in pisali. Vsekakor pa se $\mathrm{z}$ vstopom digitalizacije $\mathrm{v}$ vse dimenzije našega življenja odnos do načina dojemanja sveta literature in knjige spreminja. Mnogokrat smo prikrajšani za tiste lepe občutke pri obračanju listov knjige ali ob posebnem vonju kupa starih knjig na knjižni polici. Menim, da ima knjiga za Slovence velik simbolen pomen, zato je naša odgovornost, da še naprej spodbujamo slovensko založništvo, tudi prevajalce ter kvalitetne knjižne programe.

5. Ljubezen do slovenskega naroda in jezika se kaže skozi priznavanje slovenščine kot jezika nas vseh, tudi najranljivejših. 
Prej omenjene nove tehnologije in digitalni razvoj so tisti, ki lahko jezik posamezniku tudi približajo. To še posebej velja za različne ranljive skupine in osebe s posebnimi potrebami, ki za jezikovno sporazumevanje sicer uporabljajo drugačne poti, morajo pa biti enakovredne običajnim. Danes imamo na voljo glasovne slovarje, slovarje z gibljivimi slikami, sintetizatorje govora in druga orodja, ki jim omogočajo boljše izražanje v maternem jeziku.

Morda se kdaj premalo zavedamo, kaj pomeni, da je slovenščina skupen jezik res vsem državljankam in državljanom Republike Slovenije. Zato je pomembna pobuda, ki jo iskreno podpiram, da se v ustavo zapiše pravica do uporabe slovenskega znakovnega jezika kot maternega in avtohtonega jezika njegovih uporabnikov, gluhih, naglušnih in gluhoslepih. Tako bomo naredili pomemben korak k enakopravnemu priznavanju jezika, skupnosti uporabnikov pa omogočili, da se učijo v svojem jeziku in o svojem jeziku.

Spoštovane, spoštovani, slovenščina je živ in vitalen jezik. Je ena najprepoznavnejših prvin naše identitete. Med drugim ima največje število narečij na svetu glede na število prebivalcev, ki jo uporabljajo kot materni jezik. Bodimo ponosni na to bogastvo besed in posebnosti naše jezikovne skupnosti.

Slovenščina se razvija in spreminja, vendar presenetljivo mnogo počasneje, kot se je spreminjala do in v 16. stoletju. Ostaja temeljni gradnik našega naroda, kljub pojavu novega slovenskega besedja, v katerem se zrcalijo predvsem posledice aktualnih družbenih in tehnoloških sprememb.

Verjamem, da slovenščina ni ogrožena in bo prisotna zaradi svojih posebnosti, značilnosti in izjemnosti jezikovne strukture. Poskrbimo, da bo raba slovenščine stvar vzgoje, da jo bodo mladi znali govoriti in jo bodo predvsem radi uporabljali. Za vse nas pa naj ostaja močna vez, ki nas združuje, vir naše samobitnosti in steber notranje moči naše države.

Draga Slovenija, želim ti vse dobro! 